\title{
Multimorbidity and Quaternary Prevention (P4)
}

\author{
Multimorbidade e Prevenção Quaternária (P4)

\section{Multimorbilidad y Prevención Cuaternaria (P4)}

Dee Mangin. David Braley Nancy Gordon Chair in Family Medicine, Department of Family Medicine, McMaster University. Hamilton, Ontario, Canada. mangind@mcmaster.ca (Corresponding author)

Iona Heath. Retired general practitioner. Immediate Past President of the Royal College of General Practitioners. London, United Kingdom. iona.heath22@yahoo.co.uk

\section{Abstract}

Multimorbidity has become the norm for the majority of patients attending primary care, and while the proportion of those with multimorbidity is higher in older age, the absolute number of people with multimorbidity is greater in those under 65. The specialist-based single-disease model of treatment assumes that each index disease is the dominant illness within the complex system and that the other comorbid illnesses are held constant while management is focussed on the single condition. Thus, applying single disease guidelines to a person with five chronic comorbidities, no matter what they are, results in potentially harmful polypharmacy. This approach has led to the current 'epidemic' in morbidity and mortality from adverse drug reactions that now outstrip the target diseases as a cause of death. In this article, we highlight four characteristics of quaternary prevention framework that policymakers should take into account when considering the quality of health care.

\section{Resumo}

A multimorbidade se tornou a norma para a maioria dos pacientes atendidos nos serviços de atenção primária à saúde, e enquanto a proporção de pessoas com multimorbidade é maior em idades mais avançadas, o número absoluto de pessoas com multimorbidade é maior em pessoas com menos de 65 anos. 0 modelo de tratamento de doença única, com base no especialista focal, pressupõe que cada doença-índice seja a doença dominante dentro de um sistema complexo e que as outras comorbidades se mantenham constantes, enquanto o seu manejo é centrado em uma única condição. Assim, aplicando-se as diretrizes de doenças-únicas para uma pessoa com cinco comorbidades crônicas, não importando quais sejam elas, resulta em uma polifarmácia, potencialmente nociva. Esta abordagem tem conduzido a atual "epidemia" da morbidade e mortalidade por reações adversas a medicamentos, que já ultrapassa as doenças-alvo como causas de morte. Neste artigo, destacam-se quatro características da prevenção quaternária, que gestores de saúde deveriam levar em conta ao considerarem a qualidade dos cuidados em saúde.

\section{Resumen}

La multimorbilidad se convirtió en la norma para la mayoría de los pacientes que acuden a la atención primaria, y mientras que la proporción de los que tienen multimorbilidad es mayor en la edad avanzada, el número absoluto de personas con multimorbilidad es mayor en los menores de 65 años. El modelo de tratamiento de enfermedad-única, basado en el especialista focal, supone que cada enfermedad-índice es la enfermedad dominante en un sistema complejo, y que las otras comorbilidades se mantienen constantes, mientras que su manejo es centrado en una única condición. Así, las directrices de enfermedades-únicas para una persona con cinco comorbilidades crónicas, no importando cuales sean ellas, resulta en una polifarmacia, potencialmente dañosa. Este enfoque ha dado lugar a la actual "epidemia" de morbilidad y mortalidad debido a las reacciones adversas a los medicamentos, que ya superan las enfermedades-objetivo como causas de muerte. En este artículo, se destacan cuatro características de la prevención cuaternaria, que los administradores de salud deberían tener en cuenta al considerar la calidad de la atención de salud.

\section{Keywords:}

Health of the Elderly

Comorbidity

Drug Interactions

Medicalization

Quaternary Prevention

\section{Palavras-chave:}

Saúde do Idoso Comorbidade Interações de Medicamentos Medicalização Prevenção Quaternária

\section{Palabras clave:}

Salud del Anciano Comorbilidad Interacciones de Drogas Medicalización Prevención Cuaternaria

\begin{tabular}{l}
\hline Funding: \\
none declared. \\
Ethical approval: \\
not applicable. \\
Competing interests: \\
none declared. \\
Provenance and peer review: \\
commissioned by the editors, \\
not externally reviewed. \\
Received: 04/12/2014. \\
Accepted: 14/01/2015.
\end{tabular}

Funding: Competing interests: none declared. Provenance and peer review: not externally reviewed. 


\section{The Challenge of Multimorbidity}

When patients suffer more than one illness or disease simultaneously, they are described as having multimorbidity and this is the biggest challenge facing contemporary medical care. ${ }^{1}$ It is well understood that multimorbidity is the norm for the majority of patients attending primary care, and while the proportion of those with multimorbidity is higher in older age, the absolute number of people with multimorbidity is greater in those under $65 .^{2}$

There is also general agreement that neither the current theoretical framework of medicine nor the practical structure of medical care is fit for purpose when dealing with multimorbidity. The experience of chronic illnesses by patients is highly variable. ${ }^{3,4}$ The specialist-based single-disease model of treatment assumes that each index disease is the dominant illness within the complex system, and that the other comorbid illness are held constant while management is focussed on the single condition. This siloing results in complex, chaotic care that is confusing for the patient.

Applying single disease guidelines to a person with five chronic comorbidities, no matter what they are, results in potentially harmful polypharmacy. ${ }^{5}$ One study found that applying individual disease guidelines to a patient with five chronic conditions would result in the prescription of 19 doses of 12 different drugs, taken at five time points during the day, and carrying the risk of 10 attendant interactions or adverse events. ${ }^{5}$ In such situations, measurably better care may be meaningfully worse for the patient. In fact the evidence base for treatments in the context of multimorbidity is poor, as such patients are excluded from clinical trials. It is likely that multimorbidity attenuates the effect size of treatments, however the extent to which this occurs is unknown. There is therefore little information for doctors and patients on the expected benefits of these treatments in the context of multimorbidity against which to balance the harms.

The siloed approach to treatment decision making has led inevitably to polypharmacy, and the current 'epidemic' in morbidity and mortality from adverse drug reactions that now outstrips the target diseases as a cause of death. Older adults are now taking a mean of seven medications in most developed countries and those taking $>5$ medications are more likely to experience a medication related side effect that requires health care than those taking <2 (13\% vs 6\%). ${ }^{6}$ Adverse drug events are listed in the top five causes of death in many developed countries, and rates of hospital admission for this indication in people over 65 are estimated at 17\%. This is an important, expensive, and iatrogenic source of morbidity in people with multiple chronic conditions. Each year more people die of adverse drug effects in Europe alone than die of colon cancer, or breast cancer, or prostate cancer. ${ }^{7,8}$ It is the equivalent of more than two jumbo jets crashing and killing all on board every day. If this was an airline, would you fly on it? Patients do, and they do it every day. Yet this cause of death and illness is largely lost in the hype around the epidemics of cardiovascular disease or cancer. There are no preventive measures in place to prevent death from this far more common yet largely invisible cause. In Canada, less than half of those taking more than five medications report having a medication review. ${ }^{6}$

This overtreatment has been embedded by policies and increasing top down micromanagement of care based on single disease guidelines, and often incentivised by payment linked to adherence to these guidelines. ${ }^{9,10}$ While benevolently applied in most cases, this medical care may actually add to the dual burdens of multimorbidity and its social causes and overwhelm the capacity the patient has to participate in their own healthcare. This inappropriate model of care increases health inequity, as multimorbidity is experienced to a greater degree by the more deprived, and this group are least resourced to manage adverse drug effects. The ensuing morbidity and mortality places an enormous and unsustainable burden on health budgets. In Canada, adverse drug events (ADEs) give rise to over 70,000 preventable admissions per year. ${ }^{11}$ Estimates suggest that for every million older adults, 27 million dollars are lost in the costs of avoidable adverse drug events each year. ${ }^{12}$ Polypharmacy can also waste the potential benefits of treatment. When the number of pills leads to confusion, it is often impossible to take them all as such confusion reduces an individual's capacity to participate in their own care. ${ }^{13}$ Approximately $50 \%$ of patients with chronic diseases follow treatment recommendations. ${ }^{14}$ One study found only $27 \%$ of patients with recent heart failure admission were compliant with medication they had been prescribed on hospital discharge. ${ }^{15}$ Perceived side effects and discordance between patients and doctors around treatment goals and decisions influence non-adherence as much as difficulty remembering to take medication. ${ }^{16}$ In the absence of conversations to prioritise medicines according to patients' goals for care, the pills that get skipped might also be the ones likely to be most helpful.

Multimorbidity is tacitly understood to mean a combination of diseases, but a disease label is not synonymous with illness. An individual focuses on their own problems and on their subjective experience of pain or distress, influenced by their particular biographical context and their perception of what is normal and what is not. The medical/epidemiological gaze is increasingly focussed on pathological processes, diagnostic labels and now on risk factors for disease in populations. 
Attention has shifted away from the actuality of patient experience towards defining disease on the basis of biomarkers. Hypertension, hypercholesterolemia and other biomedical markers are not diseases, but are increasingly viewed, described and managed as though they were. Preventive activities are the basis of the marketing of medicines and the taxonomies of both disease and disease risk have been adapted incrementally to meet the needs of the pharmaceutical industry. ${ }^{17}$ For example, it is now common for population health agencies and research papers worldwide to talk of hypertension as a disease or comorbidity. ${ }^{18-20}$ This leads both to long term treatments being given to individuals who are not suffering from illness, and the seemingly harmless act of giving these patients a label. However this seemingly harmless act demonstrably leads to poorer health outcomes. A recent study showed poorer self-rated health as a result of disease labelling on the basis of three asymptomatic physiological measures (hypertension, diabetes and thyroid disease).$^{21}$ Living with multiple chronic illnesses is already associated with psychological distress. Adding labels that extend this range is likely to increase this further. Such labelling is not justifiable nor necessary. Physiological markers such as blood pressure and glycaemia have associations with subsequent illness but they do not inevitably lead to illness. These associations are even less certain for older people. Levels considered abnormal in younger patients are normal in older patients and associated with better health - cholesterol level is a good example of this, as is blood pressure. The putative overall benefits of any treatment are equally uncertain in a situation of both multimorbidity and in older seniors. It is been demonstrated repeatedly that lowering glucose levels to a 'normal' range does more harm than good in older adults, and that being on an antihypertensive in older old age increases the risk of serious injury due to a fall. ${ }^{22,23}$ Trying to target treatment at what is normal in younger patients may increase the risk of poor health in older people.

\section{How might P4 benefit patients with multimorbidity?}

Reduction in the burden of medication and the harms of polypharmacy is a key clinical task in the face of multimorbidity but one which is not easily achievable within current medical structures. Trials of stopping medicines indicate that stopping or reducing doses of diuretics, antihypertensives, antipsychotics and proton pump inhibitors can be successful and their effectiveness is often increased by tapering. ${ }^{24-26}$ Trials of the discontinuation of multiple medications also indicate that this can be done successfully, without adverse consequences for the patient and with indications of an overall improvement in health. ${ }^{27,28}$

So how are doctors and patients to negotiate this uncertain landscape? Quaternary prevention is defined as action taken to identify patient at risk of overmedicalization, to protect him or her from further biomedical intrusion or medical invasion, and to suggest interventions that are ethically acceptable. Ethically acceptable means both interventions likely to offer a balance of benefit over harm in that individual, as well as interventions that are within the patient's capacity to incorporate given their level of biographical complexity. Using this definition as a framework, clinicians can assess whether interventions that might offer benefit in patients with single diseases have any chance of offering an overall benefit to a particular patient with multimorbidity. The P4 conceptual framework provides a useful basis for modelling safer health care for patients with multimorbidity for four reasons:

(1) It requires active consideration of not doing things - tests, treatments or labels - that may cause more harm than good. It describes and makes visible an active clinical process of avoiding overdiagnosis and overtreatment and gives a name to what doctors are actively doing when they are doing nothing. This gives confidence to individual doctors and helps policymakers to understand that this is an important, active part of the management in chronic comorbidity, and a good use of the resources they oversee on behalf of taxpayers.

(2) The relational model of P4 integrates doctors' understanding of the causal mechanisms of disease with patients' experience of illness, without giving either ascendancy. Patients experience chronic illness variably and uniquely and when multiple chronic illnesses are experienced simultaneously the experience of illness and effects of treatments becomes even more particular. Situating care within the context of the particular patient will focus on their particular experience of illness and allow them to decide what is most important, and align treatment to this. Patients' priorities for personal care may differ from medical priorities based on the science of disease. Until recently, medical priorities have been in the ascendant. Overdiagnosis and overtreatment include diagnostic labels and treatments that are not just medically inappropriate but also those that the patient doesn't want, or seek. Diagnosis of dementia is a good example, and P4 would prioritise conversations with the patient as to whether or not they wish to explore early cognitive issues over current pressure to screen for dementia. 
(3) P4 provides a method for overcoming some of the barriers to good care in patients with multimorbidity. Fear of complaints or of 'getting it wrong' compared with guidelines are barriers to stopping unhelpful treatments. With multimorbidity in particular, this increases vulnerability to excessive investigation and treatment offering no overall benefits, and adding morbidity due to drug interactions and adverse effects. Incorporating P4 'red flags' in future management guidance documents might discourage overuse of investigations and diagnoses, and incorporating $\mathrm{P} 4$ in quality measures could reward judicious prescribing and harm avoidance. This would give the doctor a marker to point to, and even record when justifying decisions not to follow single disease treatment and investigation algorithms. Decisions to add interventions would be driven by the individual's capacity to cope with them, rather than disease-driven potential benefits. This approach in turn provides some bulwark against the influence of pharmaceutical company driven mandates for treatment and the threat of personal litigation that creates perverse incentives for care.

(4) Most importantly, P4 is seated within a doctor-patient relationship that exists over time. This is completely different to the current care models for chronic disease where there is no sense that it matters who provides care as long as it gets done. An ongoing longitudinal relationship makes it more likely that the patient is 'known'. This includes their particular experiences of their illnesses, and their priorities and preferences for care. This longitudinal relationship avoids the 'conspiracy of anonymity' highlighted by Freeman et al. that results in care that attends only to the presenting issues. ${ }^{29}$ This longitudinal relationship-based care seems almost essential for the watchful waiting necessary to avoid potentially harmful investigations and treatments. It provides a basis for providing treatment that it is within the patient's capacity to implement as part of May and Montori's 'Minimally Disruptive Medicine'. ${ }^{13}$

\section{Conclusion}

Patients experience the burden of illness and their treatments, and the inequity that has led to them. P4 offers a model from which to explore an approach to medical care that tries hard not to add to this burden, and to not waste the most precious commodity of the person with multiple co-morbidities - time. It also offers a framework for policymakers to include these considerations in considering the quality of health care. Rather than looking at care from the position of comparative efficacy that is currently espoused, this takes a different position that has the patient at its heart - a position of comparative safety.

\section{References}

1. Mangin D, Heath I, Jamoulle M. Beyond diagnosis: responding to the comorbidity challenge BMJ. 2012;44:e3526. http://dx.doi.org/10.1136/bmj.e3526

2. Salisbury C, Johnson L, Purdy S, Valderas JM, Montgomery AA. Epidemiology and impact of multimorbidity in primary care: a retrospective cohort study. Br J Gen Pract. 2011;61:e12-e21. http://dx.doi.org/10.3399/bjgp11X548929

3. Davidoff F. Heterogeneity is not always noise. JAMA. 2009;302(23):2580-6. http://dx.doi.org/10.1001/jama.2009.1845

4. Starfield B. Diseases, chronic care and primary care. Sommer Memorial Lecture. Portland, Oregon: Johns Hopkins Bloomberg School of Public Health; 2010.

5. Boyd CM, Darer J, Boult C, Fried LP, Boult L, Wu AW. Clinical practice guidelines and quality of care for older patients with multiple comorbid diseases: Implications for pay for performance. JAMA. 2005;294:716-24. http://dx.doi.org/10.1001/jama.294.6.716

6. $\mathrm{ClHI}$. Seniors and the health care system: what is the impact of multiple chronic conditions? [Internet]. Canada: Canadian Institute for Health Information; 2011 [acesso em 2014 Dec 01]. Disponível em: https://secure.cihi.ca/free_products/air-chronic_disease_aib_en.pdf

7. Commission E. Strengthening pharmacovigilance to reduce adverse effects of medicines. Brussels: European Commission; 2008 [acesso em 2014 Dec 01]. Disponível em: http://europa.eu/rapid/press-release_MEMO-08-782_en.htm?locale=en

8. Malvezzi M, Bertuccio P, Levi F, La Vecchia C, Negri E. European cancer mortality predictions for the year 2013. Ann Oncology. 2013;24:792-800. http://dx.doi.org/10.1093/annonc/mdt010

9. Starfield B, Mangin D. An international perspective on the basis of pay-for-performance. In: Gillam S, Siriwardena AN (editors). The quality and outcomes framework (QOF): Transforming general practice. Abingdon, UK: Radcliffe; 2011. p. 147-55. 
10. Mangin D, Toop L. The Quality and Outcomes Framework: what have you done to yourselves? Br J Gen Pract. 2007;57:435-7.

11. Baker GR, Norton PG, Flintoft V, et al. The Canadian Adverse Events Study: the incidence of adverse events among hospital patients in Canada. CMAJ. 2004;170:1678-86. http://dx.doi.org/10.1503/cmaj.1040498

12. Field TS, Gilman BH, Subramanian S, Fuller JC, Bates DW, Gurwitz JH. The costs associated with adverse drug events among older adults in the ambulatory setting. Med Care. 2005;43:1171-6. http://dx.doi.org/10.1097/01.mlr.0000185690.10336.70

13. May C, Montori VM, Mair FS. We need minimally disruptive medicine. BMJ. 2009;339:b2803. http://dx.doi.org/10.1136/bmj.b2803

14. WHO. Adherence to long-term therapies: evidence for action. Geneva: World Health Organization; 2003.

15. Cline CMJ, Björck-Linné AK, Israelsson BYA, Willenheimer RB, Erhardt LR. Non-compliance and knowledge of prescribed medication in elderly patients with heart failure. Eur J Heart Fail. 1999;1:145-9. http://dx.doi.org/10.1016/S1388-9842(99)00014-8

16. Vervloet M, Linn AJ, van Weert JCM, de Bakker DH, Bouvy ML, van Dijk L. The effectiveness of interventions using electronic reminders to improve adherence to chronic medication: a systematic review of the literature. J Am Med Inform Assoc. 2012; 696-704. http://dx.doi.org/10.1136/amiajnl-2011-000748

17. O'Donnell JL, Smyth D, Frampton C. Prioritizing health-care funding. Intern Med J. 2005;35:409-12. http://dx.doi.org/10.1111/j.1445-5994.2005.00839.x

18. Public Health England. Disease prevalence model. England; 2013 [acesso em 2014 Dec 01]. Disponível em: http://www.apho.org.uk/DISEASEPREVALENCEMODELS

19. Long AN, Dagogo-Jack S. Comorbidities of diabetes and hypertension: mechanisms and approach to target organ protection. J Clin Hypertens (Greenwich). 2011;13:244-51. http://dx.doi.org/10.1111/j.1751-7176.2011.00434.x

20. Institute of Medicine. Living well with chronic illness: a call for public health action. Washington: Institute of Medicine; 2012.

21. Jørgensen P, Langhammer A, Krokstad S, Forsmo S. Is there an association between disease ignorance and self-rated health? The HUNT Study, a cross-sectional survey. BMJ Open 2014;4: e004962. http://dx.doi.org/10.1136/bmjopen-2014-004962

22. Tinetti ME, Han L, Lee DH, et al. Antihypertensive medications and serious fall injuries in a nationally representative sample of older adults. JAMA Intern Med. 2014;174(4):588-595. http://dx.doi.org/10.1001/jamainternmed.2013.14764

23. The Action to Control Cardiovascular Risk in Diabetes Study Group*. Effects of intensive glucose lowering in type 2 diabetes. N Engl J Med. 2008;358:2545-59. http://dx.doi.org/10.1056/NEJMoa0802743

24. Iyer S, Naganathan V, McLachlan AJ, Le Conteur DG. Medication withdrawal trials in people aged 65 Years and older. Drugs Aging. 2008;25:1021-31. http://dx.doi.org/10.2165/0002512-200825120-00004

25. Nelson MR, Reid CM, Krum H, Muir T, Ryan P, McNeil JJ. Predictors of normotension on withdrawal of antihypertensive drugs in elderly patients: prospective study in second Australian national blood pressure study cohort. BMJ. 2002;325:815-7. http://dx.doi.org/10.1136/bmj.325.7368.815

26. Campbell AJ, Robertson MC, Gardner MM, Norton RN, Buchner DM. Psychotropic medication withdrawal and a home-based exercise program to prevent falls: a randomized, controlled trial. J Am Geriatr Soc. 1999;47:850-3.

27. Garfinkel D, Mangin D. Feasibility study of a systematic approach for discontinuation of multiple medications in older adults: addressing polypharmacy. Arch Intern Med. 2010;170:1648-54. http://dx.doi.org/10.1001/archinternmed.2010.355

28. Garfinkel D, Zur-Gil S, Ben-Israel J. The war against polypharmacy: a new cost-effective geriatric-palliative approach for improving drug therapy in disabled elderly people. Isr Med Assoc J. 2007;9:430-4. 